\title{
ADGRG6 Gene
}

National Cancer Institute

\section{Source}

National Cancer Institute. ADGRG6 Gene. NCI Thesaurus. Code C153050.

This gene plays a role in development of the heart and nervous system and in stature. 